Revta brasil. Bot., São Paulo,V.24, n.4 (suplemento), p.501-510, dez. 2001

\title{
Germinação in vitro e embriogênese somática a partir de embriões imaturos de canela sassafrás (Ocotea odorifera Mez)
}

\author{
CLAUDETE SANTA-CATARINA ${ }^{1}$, SCHEILA DA CONCEIÇÃO MACIEL ${ }^{1}$ e ENIO LUIZ PEDROTTI ${ }^{1,2}$
}

(recebido: 4 de setembro de 2000; aceito: 21 de fevereiro de 2001)

\begin{abstract}
In vitro germination and somatic embryogenesis from immature embryos of "canela sassafrás" (Ocotea odorifera Mez). Zygotic embryos in different developmental stages were used to study the in vitro germination potential and embryogenic competence. Fruits harvested from 15 to 360 days after the anthesis were measured to the diameter ( $\mathrm{mm}$ ), length $(\mathrm{mm})$ and fresh mass $(\mathrm{g})$. For in vitro germination, zygotic embryos in different developmental stages were inoculated on Murashigue \& Skoog (MS) medium or MS medium supplemented with $4.4 \mu \mathrm{M}$ of BAP, sucrose (3\%), agar $(0.6 \%)$ and activated charcoal $(0.15 \%)$. For the in vitro somatic embryogenesis induction, embryonic axis in different developmental stages were inoculated on MS culture medium, supplemented with 2,4-D (0, 9, 18, 72 e $144 \mu \mathrm{M})$, sucrose (3\%), agar $(0.6 \%)$ and activated charcoal $(0.15 \%)$. The fruit and zygotic embryo showed some growth up to 180 days after flowering, increasing after this period until the last harvested (360 days after the flowering). The in vitro germination was observed in immature embryos collected 240 days after the flowering, with average of $40 \%$. In the last harvesting the germination average was $80 \%$. Embryogenic cultures were induced on MS culture medium containing high concentrations of 2,4-D (72-144 $\mu \mathrm{M})$ in embryonic axis collected 150 days after flowering. Embryogenic cultures of $O$. odorifera were maintained in vitro, on MS culture medium without plant growth regulators, by repetitive secondary embryogenesis.
\end{abstract}

RESUMO - (Germinação in vitro e embriogênese somática a partir de embriões imaturos de canela sassafrás (Ocotea odorifera $\mathrm{Mez}$. Embriões zigóticos em diferentes estádios de desenvolvimento foram utilizados para avaliar o potencial de germinação e competência embriogênica in vitro. Frutos coletados entre 15 e 360 dias após a antese foram avaliados em relação ao diâmetro $(\mathrm{mm})$, comprimento $(\mathrm{mm})$ e massa fresca $(\mathrm{g})$. Para avaliar a percentagem de germinação in vitro, embriões zigóticos em diferentes estádios de desenvolvimento foram inoculados em meio de cultura composto de sais minerais de Murashigue \& Skoog (MS), ou em meio MS suplementado com 4,4 $\mu \mathrm{M}$ de BAP, sacarose (3\%), ágar (0,6\%), carvão ativado (0,15\%). Para a indução de embriogênese somática, eixos embrionários em diferentes estádios de desenvolvimento foram inoculados em meio de cultura MS, suplementado com 2,4-D $(0,9,18,72$ e $144 \mu \mathrm{M})$, sacarose (3\%), ágar ( $0,6 \%)$, carvão ativado $(0,15 \%)$. O embrião zigótico e o fruto apresentaram pequeno crescimento até 180 dias após a floração, aumentando após esta data até a última coleta (360 dias após a floração). A germinação in vitro foi observada em embriões imaturos coletados a partir dos 240 dias após a floração, com percentagem média de $40 \%$. Na última coleta a percentagem média de germinação foi $80 \%$. Culturas embriogênicas foram induzidas em meio de cultura contendo altas concentrações de 2,4-D (72-144 $\mu \mathrm{M})$ em eixos embrionários coletados a partir dos 150 dias após a floração. As culturas embriogênicas foram mantidas in vitro em meio de cultura MS desprovido de reguladores de crescimento, pelo processo de embriogênese secundária repetitiva.

Key words - zygotic embryos, somatic embryogenesis, in vitro germination, woody plant, Lauraceae

\section{Introdução}

Ocotea odorifera Mez (canela sassafrás) é uma espécie originária da Mata Atlântica do Brasil, onde foi intensamente explorada nas décadas de 40-70 para a extração do óleo de sassafrás. No estado de

1. Universidade Federal de Santa Catarina, Centro de Ciências Agrárias, Dep. de Fitotecnia, Lab. de Morfogênese e Bioquímica Vegetal, Caixa Postal 476, 88040-900. Florianópolis, SC, Brasil.

2. Autor para correspondência: pedrotti@cca.ufsc.br
Santa Catarina, esse extrativismo caracterizou-se como importante fonte de renda no Alto do Vale do Rio Itajaí, visando principalmente à exportação do óleo, para o uso na indústria alimentar, farmacêutica e agroquímica (Reitz et al. 1978). Em conseqüência disso, ocorreu uma redução na população original que resultou na inclusão dessa arbórea na lista das espécies ameaçadas de extinção (Viana et al. 1999).

A propagação sexual de genótipos da $O$. odorifera no seu local de ocorrência é dificultada, pois a produção de sementes é irregular e a sua viabilidade é baixa em virtude de ser uma espécie 
recalcitrante. Além disso, a semente é atacada por insetos e fungos antes e após a maturação fisiológica. Seu alto teor em óleo também provoca a oxidação e deterioração rápida da semente, determinando uma baixa taxa de germinação (Carvalho 1994). Outro fator limitante para a propagação dessa espécie é a baixa resposta à propagação vegetativa convencional por estaquia, que muitas espécies florestais apresentam. Dentre as principais restrições da estaquia para espécies florestais destacam-se a relação inversa da taxa de enraizamento e idade da planta mãe e o reduzido número de estacas que podem ser produzidas por planta (Högberg et al. 1998).

As técnicas da embriogênese somática e da a germinação in vitro podem ser utilizadas para a multiplicação e conservação dessa espécie, à semelhança do que se tem verificado com outras lenhosas (Jain \& Ishii 1998). Segundo Ammirato (1983), a embriogênese somática é um processo análogo à embriogênese zigótica em que, uma única célula ou um grupo de células somáticas são precursoras de embriões somáticos. Este sistema é utilizado para a propagação massal de plantas elites, apresentando grande potencial pois possibilita elevadas taxas de multiplicação (Gupta et al. 1993). Para várias espécies florestais, incluindo vários membros da família Lauraceae, como para Laurus nobilis (Canhoto et al. 1999), Persea americana Mill. (Witjaksono et al. 1999) e Ocotea catharinensis (Viana \& Mantell 1999), foi possível estabelecer protocolos de indução de embriogênese somática. Porém a indução de culturas embriogênicas depende do genótipo, tipo de explante, estádio de desenvolvimento do explante e da composição do meio de cultivo in vitro (Litz et al. 1998). O estádio de desenvolvimento dos embriões zigóticos utilizados como fonte de explante é fundamental para a expressão de seu potencial morfogenético (Chalupa 1999). A germinação in vitro de embriões zigóticos imaturos e maturos pode ser utilizada para o resgate de embriões em programas de conservação e melhoramento genético, na recuperação de híbridos de cruzamentos incompatíveis e também como fonte de explante para a cultura de tecidos (Zhang \& Lespinasse 1991).

$\mathrm{O}$ crescimento e o desenvolvimento do embrião zigótico depende da espécie, podendo durar 35 dias em Prunus (Pedrotti et al. 1992) e 140 dias em macieira (Zhang \& Lespinasse 1991). Para $O$. odorifera não foram encontrados trabalhos que demonstrassem a evolução e os estádios de desenvolvimento dos embriões zigóticos em função do tempo.

O objetivo deste trabalho foi quantificar o crescimento do fruto e do embrião zigótico em função do tempo, avaliar o potencial de indução à embriogênese somática e o potencial da germinação in vitro, a partir de embriões zigóticos e eixos embrionários em diferentes estádios de desenvolvimento.

\section{Material e métodos}

Embriões zigóticos nos estádios de desenvolvimento de pró-embrião, globular, cotiledonar inicial, cotiledonar intermediário e cotiledonar final, foram excisados de frutos coletados de plantas matrizes de canela sassafrás (Ocotea odorifera Mez) localizadas no município de Taió (SC). As coletas foram iniciadas 15 dias após a plena floração (meados de fevereiro) e a última coleta foi realizada aos 360 dias após a plena floração (final de fevereiro do ano seguinte), totalizando 13 coletas. Os frutos foram submetidos a um processo de desinfestação, em câmara de fluxo laminar, mediante a imersão em etanol $70 \%(\mathrm{v} / \mathrm{v})$, durante 5 minutos, hipoclorito de sódio $2 \%(\mathrm{v} / \mathrm{v})$ por 30 minutos, etanol $70 \%(\mathrm{v} / \mathrm{v})$ por 1 minuto e em seguida de três lavagens com água destilada autoclavada. Para as fases de germinação in vitro e indução da embriogênese somática, os embriões zigóticos e eixos embrionários foram inoculados sobre o meio de cultura composto de sais minerais e vitaminas de MS (Murashigue \& Skoog 1962), suplementado com sacarose (3\%), carvão ativado $(0,15 \%)$ e ágar $(0,6 \%)$. O $\mathrm{pH}$ foi ajustado para 5,8 antes da autoclavagem.

Desenvolvimento do fruto e do embrião zigótico - Os frutos e embriões zigóticos foram avaliados em relação ao diâmetro $(\mathrm{mm})$, comprimento $(\mathrm{mm})$ e massa fresca $(\mathrm{g})$ após cada coleta. O delineamento experimental foi inteiramente casualizado. Cada unidade experimental foi constituída de 10 frutos com 3 repetições. Germinação in vitro - Embriões zigóticos imaturos em diferentes estádios de desenvolvimento, foram inoculados em meio composto de sais minerais e vitaminas de MS sem reguladores de crescimento ou suplementado com 6benzilaminopurina (BAP) $(4,4 \mu \mathrm{M})$ para avaliar o potencial de germinação in vitro (figura $1 \mathrm{~A}$ ). As culturas foram mantidas em sala de crescimento com temperatura de $25+1{ }^{\circ} \mathrm{C}$, permanecendo durante 5 dias no escuro e posteriormente foram transferidas para sala de crescimento com intensidade luminosa de $40 \mu \mathrm{mol} . \mathrm{s}^{-1} \cdot \mathrm{m}^{2}$ e fotoperíodo de 16 horas. O delineamento experimental foi inteiramente casualizado. Cada unidade experimental foi constituída de 8 embriões zigóticos com 3 repetições. Dados de percentagem de germinação foram coletados após 50 dias em cultura.

Indução da embriogênese somática - Eixos embrionários imaturos foram inoculados em meio de cultura composto de sais minerais e vitaminas de MS suplementado com ácido 2,4- 


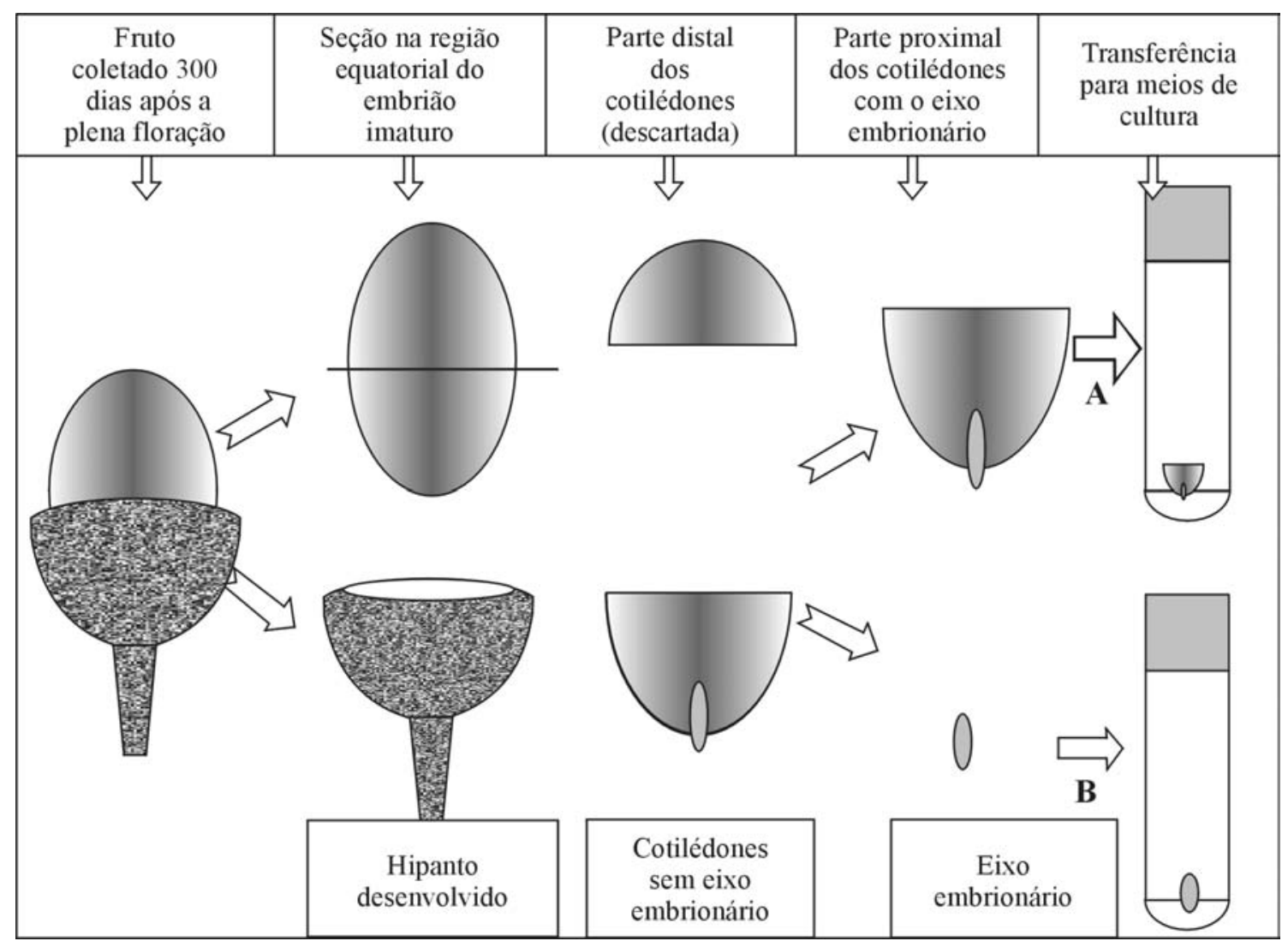

Figura 1. Representação esquemática da segmentação dos frutos e separação do embrião zigótico e eixo embrionário de Ocotea odorifera Mez A. embrião zigótico utilizado para estudos de germinação in vitro. B. eixo embrionário utilizado para a indução da embriogênese somática.

diclorofenoxiacético (2,4-D) $(0,9,18,72$ e $144 \mu \mathrm{M})$ para a indução da embriogênese somática (figura 1B). As culturas foram mantidas no escuro, em sala de crescimento na temperatura de $25+1{ }^{\circ} \mathrm{C}$. O delineamento experimental foi inteiramente casualizado. Cada unidade experimental foi constituída de 8 eixos embrionários com 3 repetições. Dados de percentagem de indução embriogenética foram coletados após 90 dias em cultura.

Manutenção das culturas embriogênicas - Culturas embriogênicas induzidas foram transferidas para meio de cultura composto de sais minerais e vitaminas de MS: 1) desprovido de reguladores de crescimento; 2) suplementado com 2,4-D $(9 \mu \mathrm{M})$ e cinetina $(4,6 \mu \mathrm{M})$ e 3$)$ suplementado com 2,4-D (72 ou $144 \mu \mathrm{M})$. As culturas foram mantidas no escuro, em sala de crescimento na temperatura de $25+1{ }^{\circ} \mathrm{C}$. Análise estatística dos dados - Os dados obtidos foram submetidos à análise de variância (ANOVA) e ao teste de separação de médias SNK (5\%), com auxílio do programa estatístico Stagraphics 7.0. Os dados de percentagem de germinação e de indução de embriogênese somática foram transformados para raiz quadrada de $\mathrm{X}+1$.

\section{Resultados}

Desenvolvimento do fruto e do embrião zigótico $O$ desenvolvimento do embrião zigótico de $O$. odorifera foi identificado pelos estádios de próembrião, que ocorre no período após a floração (figura 2) até 50 dias; estádio globular, observado em frutos coletados entre 50 até 70 dias após a floração; estádio cotiledonar inicial, observado em frutos com 90 (figura 3) até 150 dias após a floração; estádio cotiledonar intermediário, observado em frutos coletados no período entre 180 e 300 dias após a floração (figura 4) e o estádio cotiledonar final, o qual foi observado em frutos coletados no período entre 330 à 360 dias após a floração (figura 5).

Entre o período da floração até 150 dias após, foi observado um pequeno crescimento do fruto e do embrião para os parâmetros massa fresca (figura $6 \mathrm{~A}$ ), 

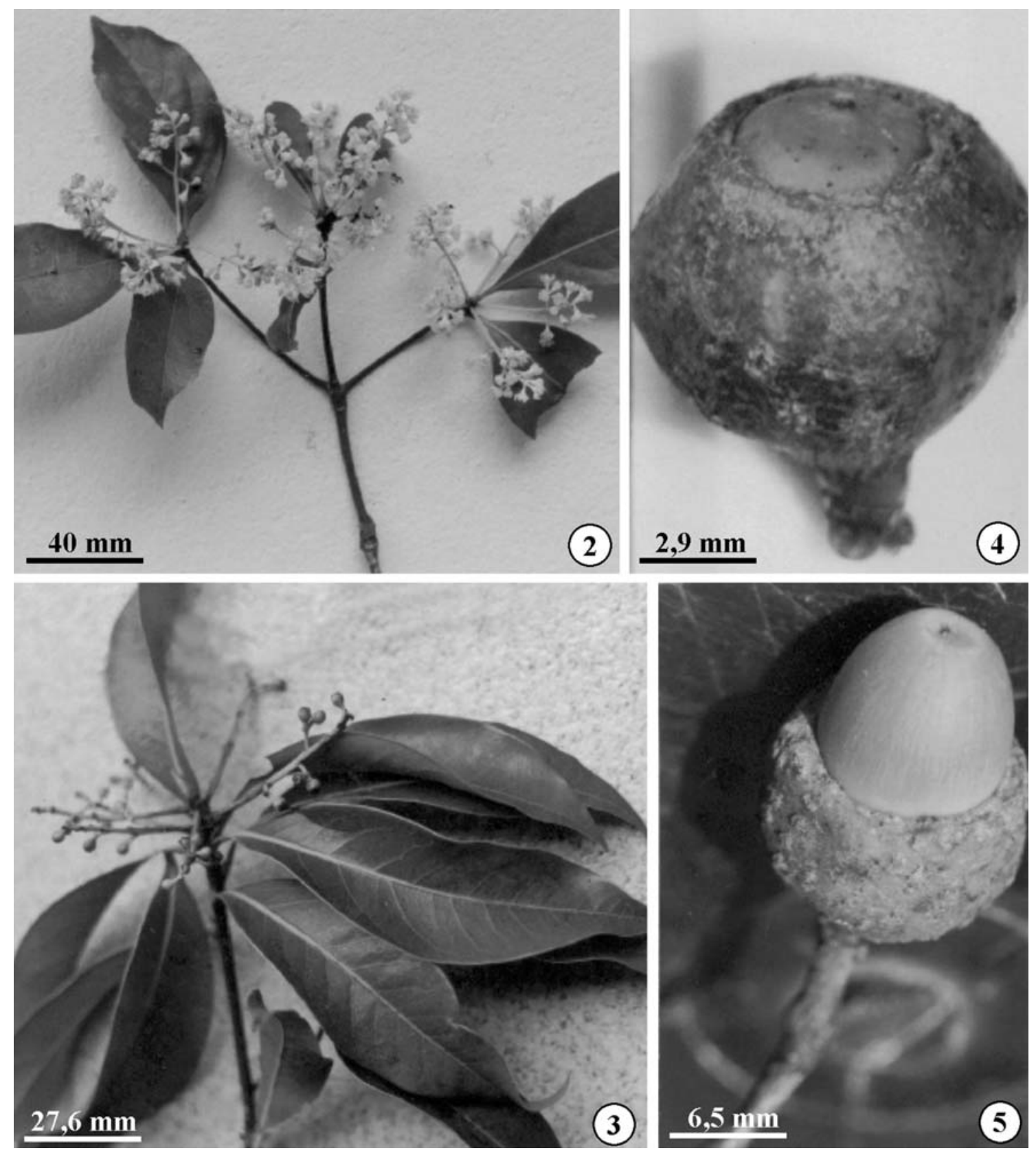

Figura 2-5. Desenvolvimento do fruto da canela sassafrás (Ocotea odorifera Mez). 2. Ramo com inflorescência em plena floração. 3. Ramo com frutos aos 90 dias após floração. 4. Fruto aos 240 dias após a floração. 5. Fruto aos 360 dias após a floração.

comprimento (figura 6B) e diâmetro (figura 6C). No período entre 180 e 300 dias após a floração foi observado incremento no crescimento do fruto e do embrião zigótico de forma exponencial e, aos 360 dias após a floração, tanto o fruto quanto o embrião atingiram o ponto máximo de crescimento em massa fresca, comprimento e diâmetro, como pode ser observado na figura $6 \mathrm{~A}, \mathrm{~B}$ e C.

Germinação in vitro - A maior percentagem média de germinação in vitro $(78,5 \%)$ foi obtida com o 

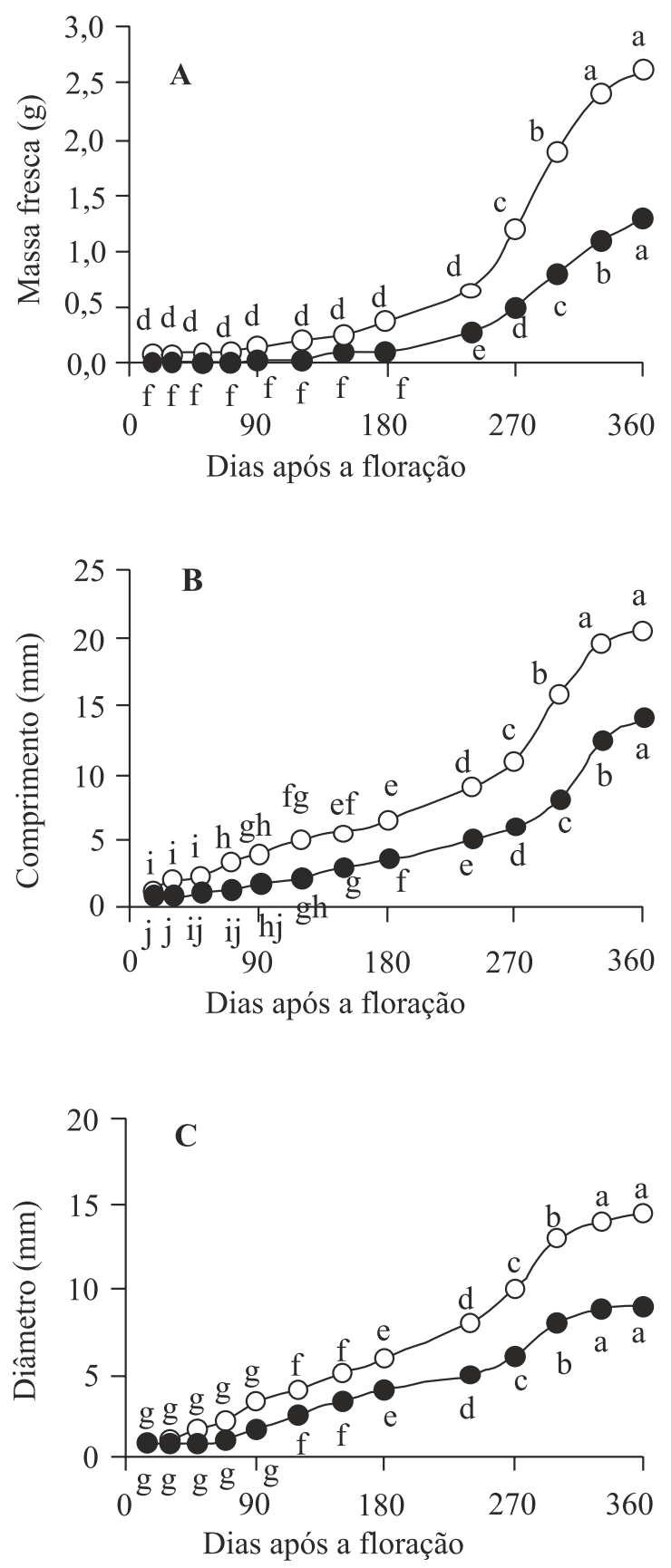

Figura 6. Desenvolvimento do fruto e do embrião zigótico de Ocotea odorifera Mez nos períodos de coleta (dias após a floração). A. Massa fresca (g); B. Comprimento (mm); C. Diâmetro $(\mathrm{mm})$. Letras diferentes indicam diferenças estatísticas ao nível de 5\% (teste SNK) para os parâmetros massa fresca, comprimento e diâmetro, em relação ao crescimento do fruto e do embrião zigótico nos períodos de coleta. $\multimap-$ - Fruto $\longrightarrow$ Embriãa uso de embriões zigóticos coletados aos 360 dias após a floração, 50 dias após a inoculação (figura 7), diferindo significativamente da percentagem de germinação obtida nas demais coletas. Nas condições estabelecidas, o potencial de germinação in vitro de embriões zigóticos de $O$. odorifera foi observado somente a partir de 240 dias após a floração, independente do meio de cultura utilizado. A concentração de BAP utilizada (0 ou $4,4 \mathrm{mM})$ não apresentou, pela análise da variância, diferenças significativas na percentagem de germinação dos embriões zigóticos. O início da germinação, emissão da radícula pelo embrião, ocorreu entre 20 e 30 dias após a introdução no meio de cultura (figura 8). Plântulas com 70 dias em cultura apresentaram uma altura média de $8 \mathrm{~cm}$ e com potencial para estudos da morfogênese in vitro.

Indução da embriogênese somática - A adição de 72 ou $144 \mu \mathrm{M}$ de 2,4-D ao meio de cultura composto de sais minerais e vitaminas de MS apresentaram as maiores percentagens médias de indução com 3,8 e 5,1\%, respectivamente, não diferindo estatisticamente entre si (tabela 1). O uso de eixos embrionários coletados em 240 dias após dias a floração revelou a maior percentagem de média de indução de culturas embriogênicas com $6,5 \%$, não diferindo estatisticamente da percentagem média de indução obtida de eixos embrionários coletados em 270 e 300 dias após a floração, com 4,1\% (tabela 1). Somente eixos

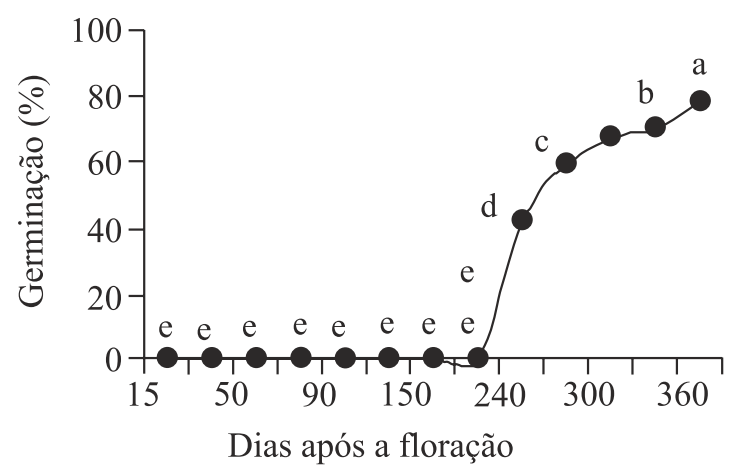

Figura 7. Percentagem de germinação dos embriões zigóticos de Ocotea odorifera Mez nos períodos de coleta (dias após a floração) após 50 dias de cultivo in vitro em meio de cultura composto de sais minerais e vitaminas de MS suplementado com 0 ou $4,4 \mu \mathrm{M}$ de BAP. Letras diferentes indicam diferenças estatísticas ao nível de 5\% (teste SNK) para a percentagem de germinação nos períodos de coleta. 
Tabela 1. Indução (\%) de culturas embriogênicas de Ocotea odorifera a partir de embriões zigóticos coletados em diferentes períodos e inoculados em meio de cultura composto de sais minerais e vitaminas de MS suplementado com sacarose (3\%), carvão ativado $(0,15 \%)$, agar $(0,6 \%)$ e 2,4-D $(0,9,18,72$ e $144 \mu \mathrm{M})$. Letras diferentes apresentam valores estatisticamente diferentes pelo teste de SNK ao nível de 5\%. Letras maiúsculas comparam a percentagem média de indução para cada concentração de 2,4-D (linha) e letras minúsculas comparam a percentagem média de indução para cada coleta (coluna).

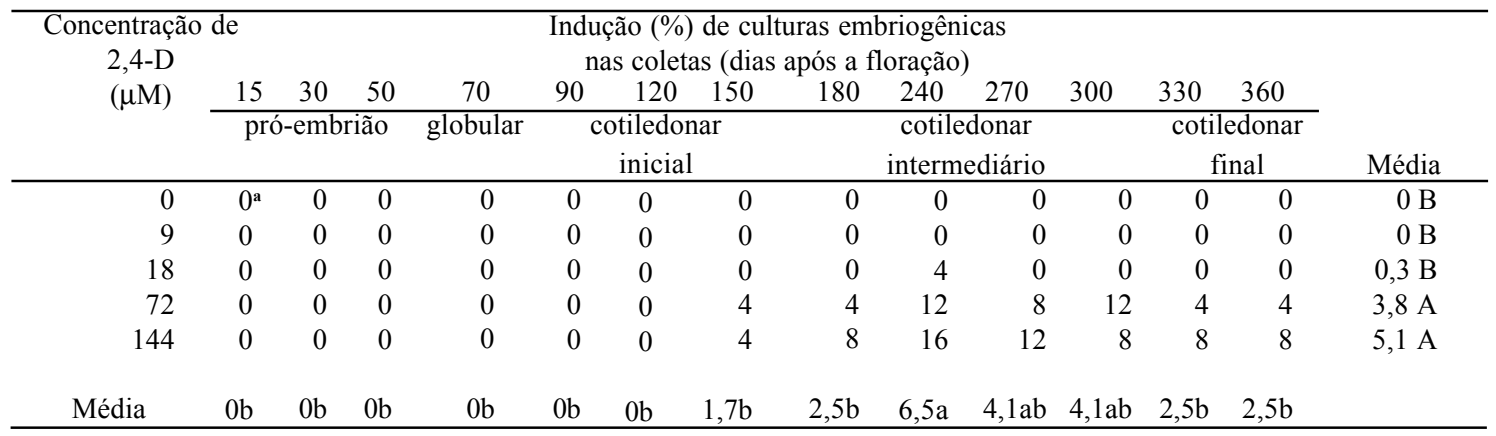

a Dados médios de percentagem de indução para cada tratamento utilizado.

embrionários excisados de frutos coletados a partir de 150 dias após a floração apresentaram potencial de indução embriogenética (figuras 9, 10). Além disso, foram observados altos níveis de contaminação (aproximadamente 40\%) dos embriões coletados até 120 dias após a floração e em todas as coletas, foi observado a oxidação dos explantes quando inoculados em meio de cultura (aproximadamente 90-100\%).

Manutenção das culturas embriogênicas - A transferência das culturas embriogênicas para meio desprovido de 2,4-D possibilitou a manutenção da competência morfogênica. Nestas condições, foram observadas a indução e multiplicação dos embriões somáticos no estádio globular (figura 11), diretamente sobre o explante transferido, que posteriormente evoluíram para o estádio cotiledonar (figuras 12, 13). Culturas embriogênicas transferidas para o meio de cultura basal suplementado com 2,4-D $(9 \mu \mathrm{M})$ e cinetina $(4,6$ $\mu \mathrm{M})$ apresentaram, visualmente, respostas semelhante àquelas encontradas quando se utilizou o meio de cultura desprovido de reguladores de crescimento. $\mathrm{O}$ meio de cultura suplementado com 2,4-D (72 ou $144 \mu \mathrm{M})$ induziu a multiplicação de embriões somáticos no estádio globular. No entanto, essas culturas apresentaram, visualmente, maior oxidação quando comparado com os demais meios de cultura testados.

Nos primeiros 20 dias após a transferência das culturas embriogênicas para os meios de cultura testados, foi observado a oxidação dessas. Sobre essas culturas oxidadas foi observada a diferenciação de novos embriões somáticos de forma direta, processo denominado de embriogênese secundária, no período entre 20 e 50 dias após a inoculação. As transferências das culturas embriogênicas para novo meio de cultura foram realizadas após 60 dias em cultivo. Embriões somáticos no estádio globular apresentaram coloração branco creme, enquanto que no estádio cotiledonar eram de coloração branco com tonalidade rosa na borda dos cotilédones.

A transferência de embriões somáticos no estádio cotiledonar para meio de cultura desprovido de reguladores de crescimento, possibilitou o desenvolvimento do meristema radicular e apical (figura 14), quando mantidos por 4 meses em cultura nessas condições.

\section{Discussão}

O crescimento do fruto e do embrião zigótico de $O$. odorifera foi semelhante ao obtido por Murneek (1954). Porém, não foi verificada uma curva típica da proporção entre o crescimento do fruto e do embrião, como foi observado para Prunus, por Pedrotti (1993). Para esta espécie o embrião só se desenvolve rapidamente quando o fruto atinge o máximo volume, enquanto que em O. odorifera, o crescimento do fruto e do embrião são concomitantes e coincidentes quanto aos 
períodos de baixo e alto incremento em massa fresca. A formação e o desenvolvimento completo do embrião de $O$. odorifera ocorre num período de 360 dias, período relativamente longo quando comparado aos embriões de outras angiospermas. Em Prunus avium, os embriões zigóticos atingem o tamanho máximo em 35 dias após a floração (Pedrotti 1993). Essa característica pode estar associada à espécie, pois $O$. odorifera é considerada uma espécie de crescimento lento, o que poderia explicar em parte esse longo período necessário para o desenvolvimento completo do embrião.

A germinação dos embriões zigóticos de $O$. odorifera foi maior quando esses apresentaram maior crescimento dos cotilédones. Aumentos na percentagem de germinação coincidentes com o maior crescimento do embrião também foram observadas para pessegueiro, por Tukey (1933) e para a cerejeira, por Pedrotti et al. (1992). Esses últimos autores constataram uma maior conexão vascular entre os cotilédones e o eixo embrionário, o que provavelmente melhorou o fluxo de nutrientes e substâncias de crescimento que foram utilizados para a germinação e o crescimento inicial dos eixos embrionários em plântulas. Nessa condição, os embriões zigóticos de $O$. odorifera embora imaturos, já podem ser coletados e introduzidos in vitro. Entretanto, embriões zigóticos dessa espécie introduzidos in vitro até 180 dias após a floração não germinaram, provavelmente porque os mesmos não haviam acumulado reservas suficientes para continuar seu completo desenvol-vimento no ambiente in vitro. A sacarose foi adicionada ao meio de cultura utilizado para a germinação, como fonte
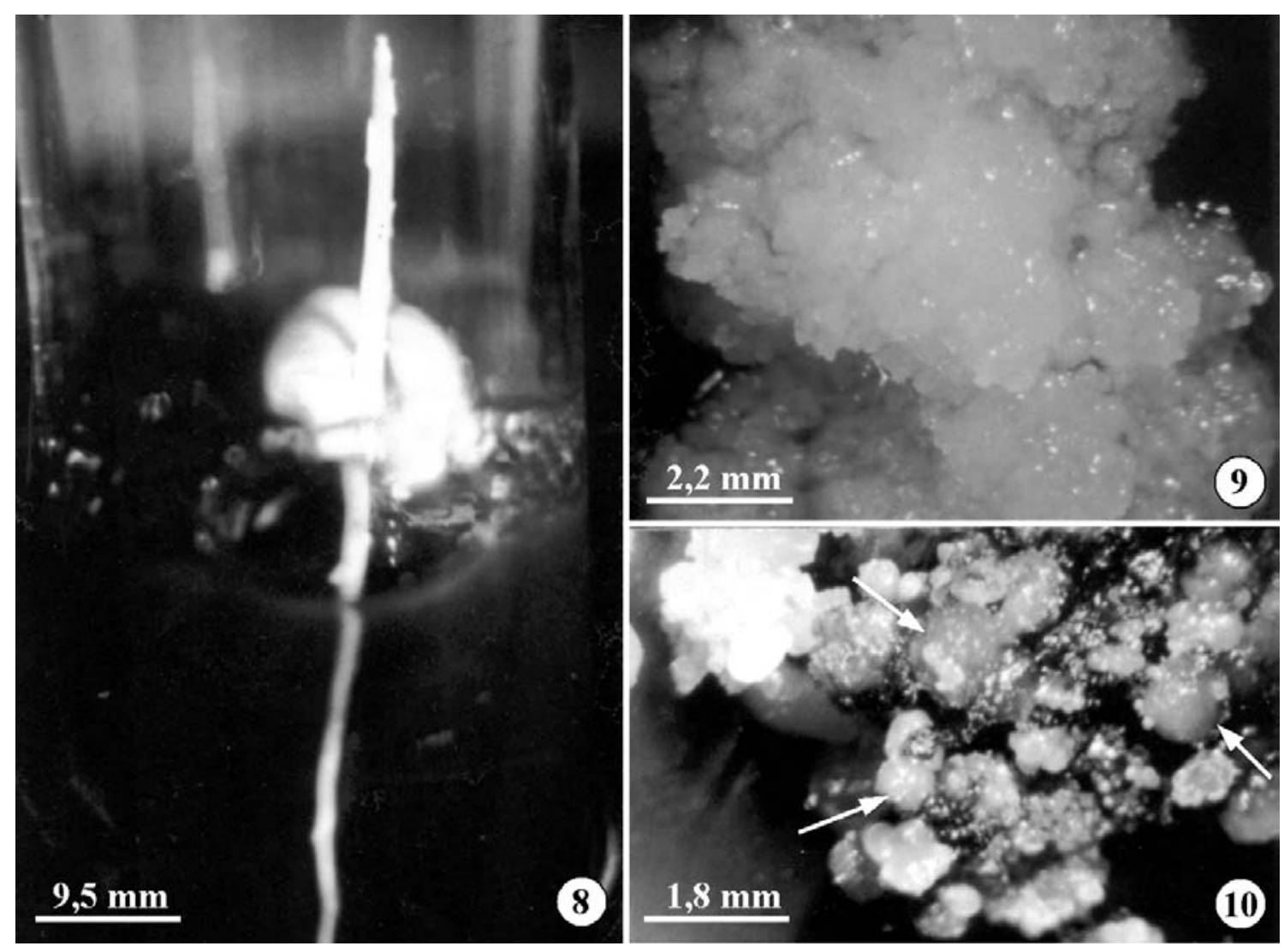

Figuras 8-10. Morfogênese in vitro de canela sassafrás (Ocotea odorifera Mez). 8. Plântula germinada in vitro, aos 50 dias em meio de cultura composto de sais minerais e vitaminas de MS. 9. Indução de culturas embriogênicas a partir de embriões zigóticos, em meio de cultura composto de sais minerais e vitaminas de MS suplementado com $144 \mu \mathrm{M}$ de 2,4-D. 10. Indução de embriões somáticos no estádio globular (setas) a partir de embriões zigóticos, em meio de cultura composto de sais minerais e vitaminas de MS suplementado com $72 \mu \mathrm{M}$ de 2,4-D. 
de carbono inicial para os embriões zigóticos de O. odorifera pois, segundo George (1996), a cultura de células, tecidos ou órgãos necessita de uma fonte de carbono visto que as mesmas apresentam um comportamento heterotrófico. Nesse sentido, Bewley \& Black (1994) demostraram que as substâncias de reserva acumuladas nos cotilédones, são necessárias para o metabolismo durante o processo de germinação dos embriões. Apesar disso, a composição do meio de cultura utilizado pode não ter fornecido os elementos nutricionais e os reguladores de crescimento necessários para completar o desenvolvimento do embrião

$A$ adição de $\mathrm{BAP}$ ao meio de cultura não apresentou efeito significativo sobre a percentagem de germinação in vitro de embriões zigóticos de $O$. odorifera, apesar de que, alguns reguladores de crescimento vegetal podem ser utilizados com o objetivo de promover a germinação e crescimento das plântulas. Nesse sentido, Zhang \& Lespinasse (1991) utilizaram o BAP e obtiveram altas taxas de germinação de embriões de macieira.
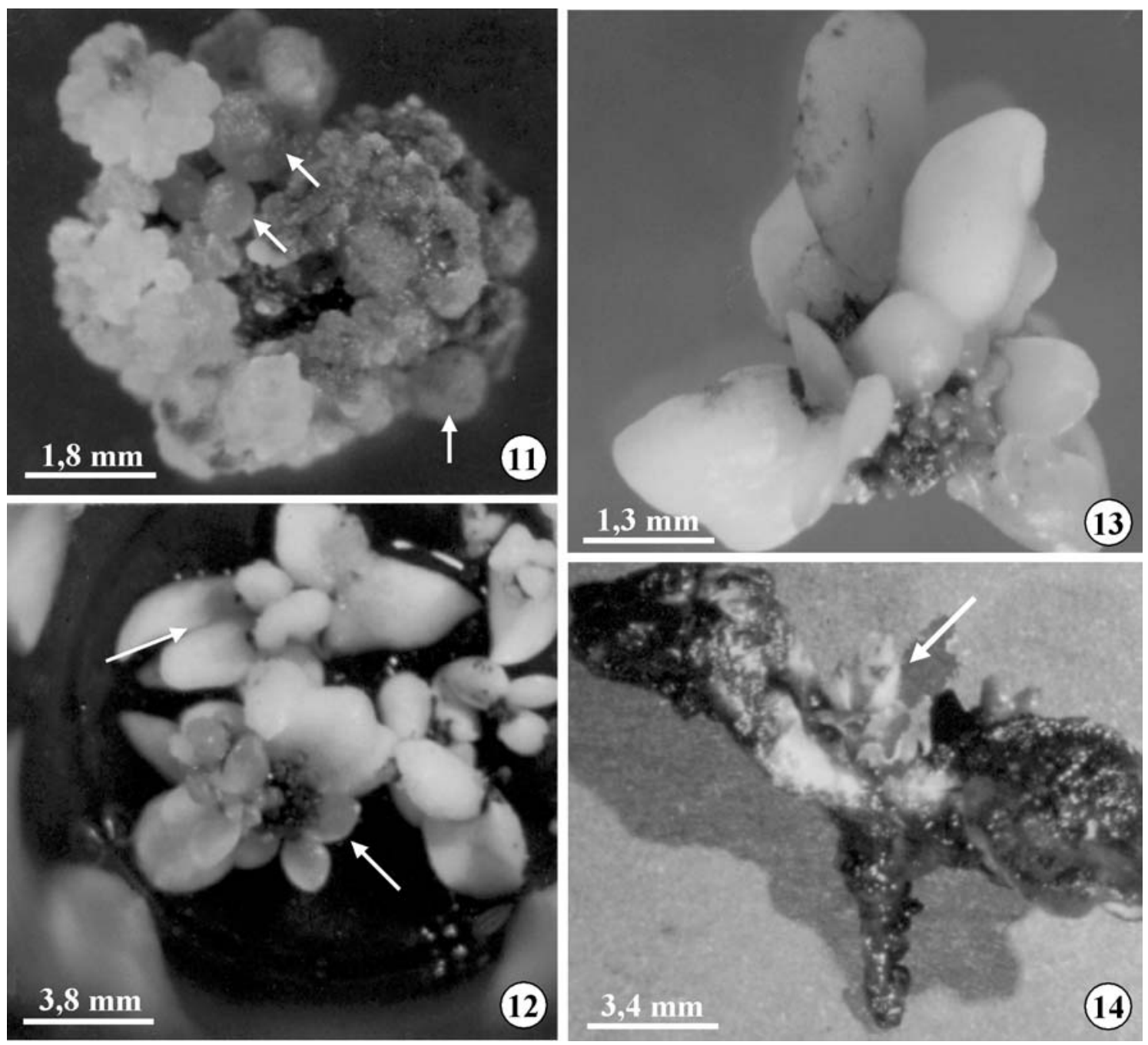

Figuras 11-14. Embriogênese somática em canela sassafrás (Ocotea odorifera Mez). 11. Embriões somáticos no estádio globular (setas) em meio de cultura composto de sais minerais e vitaminas MS 12. Embriões somáticos no estádio cotiledonar (setas) em meio de cultura composto de sais minerais e vitaminas de MS. 13. Embriões somáticos no estádio cotiledonar. 14. Embrião somático após 4 meses de cultivo em meio de cultura composto de sais minerais e vitaminas MS, mostrando o desenvolvimento do meristema radicular e apical (seta). 
Eixos embrionários de $O$. odorifera produziram culturas embriogênicas quando coletados somente a partir dos 150 dias após a floração e quando inoculados em meio de cultura composto de sais minerais e vitaminas de MS contendo 2,4-D. Em períodos anteriores a esse possivelmente, os tecidos embrionários não possuem competência ou não estão receptivos à indução com 2,4-D, como salienta Tulecke (1987). Além disso, George (1996) salienta que fatores relacionados à condição fisiológica do explante, as caraterísticas da espécie e condições experimentais, como a composição do meio de cultura e atmosfera dos frascos, podem não ter favorecido o estabelecimento da competência e recepção dos sinais para desencadear o processo de diferenciação celular.

Os resultados obtidos com $O$. odorifera diferem dos obtidos para Tilia cordata (Chalupa 1999). Para essa espécie, os períodos de 5, 6 e 7 semanas após a floração são os melhores períodos de coleta de embriões zigóticos para indução de embriogênese somática, e nessa condição, esses autores obtiveram a proliferação de calos embriogênicos em meio de cultura composto de sais minerais e vitaminas de MS suplementado com 2,4-D. Provavelmente essas diferenças são devidas ao estádio de desenvolvimento dos embriões utilizados. Em $O$. odorifera, os embriões necessitaram de um período maior para atingirem o estádio de desenvolvimento necessário para tornarem-se responsivos à indução embriogênica. Além disso, em $O$. odorifera foi observada a indução de culturas embriogênicas somente em meio de cultura contendo altas concentrações de 2,4-D. Esse resultado está de acordo com os obtidos para $O$. catharinensis, por Moura-Costa et al. (1993).

A embriogênese somática secundária possibilitou a manutenção in vitro das culturas embriogênicas de $O$. odorifera. Este processo também ocorre em muitos sistemas de embriogênese somática de espécies arbóreas (Raemakers et al. 1999). Em algumas espécies como a Mangifera indica (Litz et al. 1995) e Juglans regia (Tulecke et al. 1995), a capacidade embriogênica pode manter-se mais de 5 e 9 anos, respectivamente, via embriogênese secundária repetitiva. Além disso, em $O$. odorifera a embriogênese secundária foi mantida pela transferência das culturas em meio de cultura desprovido de reguladores de crescimento vegetal. Resultado semelhante foi obtido em $O$. catharinensis, por Viana \& Mantell (1999).

Os resultados obtidos para $O$. odorifera são promissores e mostram a viabilidade do uso desta técnica em programas de conservação desta espécie. No entanto, novos trabalhos devem ser realizados no sentido de sincronizar a indução e a expressão da embriogênese somática, controlar a embriogênese secundária, visando aumentar a percentagem de conversão dos embriões somáticos em plantas. Além disso, não é necessário aguardar a maturação completa do embrião zigótico para a germinação in vitro, diminuindo o tempo necessário para a obtenção de plantas quando comparado ao sistema natural.

Agradecimentos - Os autores agradecem ao Sr. Lírio Luiz Dal Vesco e ao Sr. Vanildo Silveira pelas sugestões na redação do manuscrito e ao $\mathrm{CNPq}$ pela concessão de bolsas e recursos financeiros

\section{Referências bibliográficas}

AMMIRATO, P.V. 1983. Embryogenesis. In Handbook of plant cell culture (D.A. Evans, W.R. Sharp, P.V. Ammirato \& Y. Yamada, eds.). Macmilian Publisher Co., New York, p.82-123.

BEWLEY, J.D. \& BLACK, M. 1994. Seeds: Physiology of development and germination. $2^{\text {nd }}$ ed. Plenum Press, New York.

CANHOTO, J.M., LOPES, M.L. \& CRUZ, G.S. 1999. Somatic embryogenesis in Bay Laurel (Laurus nobilis). In Somatic embryogenesis in woody plants (S. M. Jani, P.K. Gupta \& R.J. Newton, eds.). Kluwer Academic Publishers, Dordrecht, v. 4, p.341-367.

CARVALHO, P.E.R. 1994. Espécies florestais brasileiras: recomendações silviculturais, potencialidades e uso da madeira. Embrapa, Colombo.

CHALUPA, V. 1999. Somatic embryogenesis in linden (Tilia spp.). In Somatic embryogenesis in woody plants (S.M. Jain, P.K. Gupta \& R.J. Newton, eds.). Kluwer Academic Publishers, Dordrecht, v.5, p.31-43.

GEORGE, E.F. 1996. Plant propagation by tissue culture. $2^{\text {nd }}$ ed., Exegetics, Edington, v.1.

GUPTA, P.K., PULLMAN, G., TIMMIS, R., KREITINGER, M., CARLSON, W.C., GROB, J. \& WELTY, E. 1993. Forestry in the $21^{\text {st }}$ Century. Bio/Technology 11:454-459.

HÖGBERG, K.A., EKBERG, I., NORELL, L. \& VON ARNOLD, S. 1998. Integration of somatic embryogenesis in a tree breeding program: a case study with Picea abies. Canadian Journal of Forest Research 28:1536-1545. 
JAIN, S.M. \& ISHII, K. 1998. Recent advances in somatic embryogenesis in forest trees. In Recent advances in biotechnology for conservation and management. (S.H. Mantell, S. Bruns, C. Tragardh \& A.M. Viana, eds.). International Foundation for Science, Stockholm, p.214-231.

LITZ, R.E., CHAVEZ, V.C. \& MOON, P.A. 1998. Induction of embryogenic cultures from mature-phase tropical and subtropical trees and control of somatic embryo maturation and germination. In Recent advances in biotechnology for conservation and management (S.H. Mantell, S. Bruns, C. Tragardh \& A.M. Viana, eds.). International Foundation for Science, Stockholm, p.232-243.

LITZ, R.E., MOON, P.A., MATHEWS, H., JAYASANKAR, S., MONSALUD, M.J. \& PLIEGO-ALFARO, F. 1995. Somatic embryogenesis in mango (Mangifera indica L.). In Somatic embryogenesis in woody plants, Angiosperms, (S.M. Jain, P.K. Gupta \& R.J. Newton, eds.). Kluwer Academic Publishers, Dordrecht, v.2, p.341-357.

MOURA-COSTA, P.M., VIANA, A.M. \& MANTELL, S.H. 1993. In vitro plantlet regeneration of Ocotea catharinensis $\mathrm{Mez}$ (Lauraceae), an endangered forest tree. Plant Cell, Tissue and Organ Culture 35:279-286.

MURASHIGE, T. \& SKOOG, F. 1962. A revised medium from rapid growth and bioassays with tobacco tissue culture. Physiologia Plantarum 15:437-497.

MURNEEK, A.E. 1954. The embryo and endosperm in relation to fruit development, with special reference to the apple, Malus sylvestris. American Society Horticultural Science 64:573-582.

PEDROTTI, E.L. 1993. Etude de l'organogenèse in vitro à partir de racines, de feullies et d'embryons zygotiques de merisier (Prunus avium L.). Tese de doutorado, Université d'Orléans, Orléans.

PEDROTTI, E.L., LELU, M.A., BILLOT, I. \& CORNU, D. 1992. Morphogenetic response on wild cherry (Prunus avium L.) immature embryos. In Mass production technology for improved fast growing forest tree species. In Proceedings of symposium Bordeaux, Bordeaux, p.67-72.
RAEMAKERS, K., JACOBSEN, E. \& VISER, R. 1999. Proliferative somatic embryogenesis in woody species. In Somatic embryogenesis in woody plants (S.M. Jain, P.K. Gupta \& R.J. Newton, eds.). Kluwer Academic Publishers, Dordrecht, v.4, p.29-59.

REITZ, R., KLEIN, R.M. \& REIS, A. 1978. Projeto madeira de Santa Catarina. SUDESUL/IBDF, Itajaí.

TUKEY, H.B. 1933. Growth of peach embryo in relation to growth of fruit and season of ripening. Proceedings of American Society Horticultural Science 30:209-218.

TULECKE, W., McGRANAHAN, G.H. \& LESLIE, C.A. 1995. Somatic embryogenesis in walnut (Juglan species). In Biotechnology in agriculture and forestry, somatic embryogenesis and synthetic seed I (Y.P.S. Bajaj, ed.). Springer-Verlag, Berlin, v.30, p.370-377.

TULECKE, W. 1987. Somatic embryogenesis in woody perennials. In Cell and tissue culture in forestry (J.M. Bonga \& D.J. Durzan, eds.). Martinus Nijhoff Publisherm, Dordrecth, v.1, p.61-91.

VIANA A.M, MAZZA, M.C. \& MANTELL, S.H. 1999. Applications of biotechnology for the conservation and sustainable exploitation of plants from Brazilian Rain Forest. In Plant conservation biotechnology (E. Benson, ed.). University of Abertay, Dundee, p.277-299.

VIANA, A.M. \& MANTELL, S.H. 1999. Somatic embryogenesis of Ocotea catharinensis: an endangered tree of the mata atlântica (South Brazil). In Somatic embryogenesis in woody plants (S.M. Jain, P.K. Gupta \& R.J. Newton, eds.). Kluwer Academic Publishers, Dordrecht, v.5, p.3-30.

ZHANG, Y.X. \& LESPINASSE, Y. 1991. Removal of embryonic dormancy in apple (Malus domestica Borkh) by 6-benzylaminopurine. Scientia Horticulturae 46:215-223.

WITJAKSONO, R.E., LITZ, R.E. \& PLIEGO-ALFARO, F. 1999. Somatic embryogenesis of avocado (Persea americana Mill.). In Somatic embryogenesis in woody plants (S.M. Jain, P.K. Gupta \& R.J. Newton, eds.). Kluwer Academic Publishers, Dordrecht, v.5, p.197-214. 